Research Article

\title{
An effective acid pretreatment of agricultural biomass residues for the production of second-generation bioethanol
}

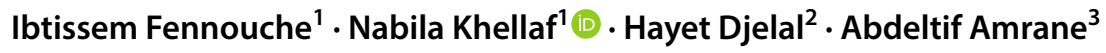

Received: 19 August 2019 / Accepted: 17 October 2019/ Published online: 24 October 2019

(c) Springer Nature Switzerland AG 2019

\begin{abstract}
Currently, the potential for energy recovery of plant biomass by biotechnological processes is a preferred solution for the use of agricultural products of low commercial value in order to produce bioenergy that is alternative to fossil fuels. The objective of this study was to obtain second-generation bioethanol by valorization of sugar beet and common dates of low quality. This involved separate hydrolysis and anaerobic fermentation process using the yeast strain Saccharomyces cerevisiae. Physicochemical and biochemical analyzes were carried out on beet and date substrates before and after alcoholic fermentation to determine their effect on yeast activity. The results showed that palm date was a good substrate for the microorganisms in contrast to sugar beet which required a high pretreatment in order to hydrolyze sucrose into fermentable sugars. After distillation, it was possible to recover bioethanol with a quality and a concentration depending on the substrate nature. For an initial sugar concentration of $12.0^{\circ} \mathrm{Brix}, 74.7 \mathrm{~g} / \mathrm{kg} \mathrm{DM}$ of bioethanol $(92.4 \mathrm{~g} / \mathrm{L})$ was produced by Saccharomyces from date syrup. In the presence of concentrated date syrup $\left(22.2^{\circ} \mathrm{Brix}\right)$, a lower efficiency of ethanol production was observed $(78.2 \mathrm{~g} / \mathrm{L})$. It can be conclude that the diluted date substrate led to a good quality bioethanol with a high production yield.
\end{abstract}

Statement of novelty In this project, we tried to valorize agricultural residues (Algerian sugar beet and palm date of low quality) for the production of bioethanol which can substitute fossil energies. Algeria is considered as one of the major producers and exporters of palm dates in the world, and thousands of tons of dates remain unused. Thus, these agricultural by-products could be recovered instead of being released into the environment by polluting it. In order to produce bioethanol, an effective pretreatment and optimal fermentation conditions were used. This project is part of a strategy to increase the feedstock exploitation and decrease the residues while producing clean and renewable energy.

$\triangle$ Nabila Khellaf, khellafdaas@yahoo.fr|'Department of Process Engineering, Faculty of Engineering, Badji Mokhtar University, P.O. Box 12, 23000 Annaba, Algeria. ${ }^{2}$ UniLaSalle-Ecole des Métiers de l'Environnement, Campus de Ker Lann, 35170 Bruz, France. ${ }^{3}$ Université de Rennes 1, ENSCR, CNRS, UMR 6226, CS 50837, 35708 Rennes, France. 


\section{Graphic abstract}

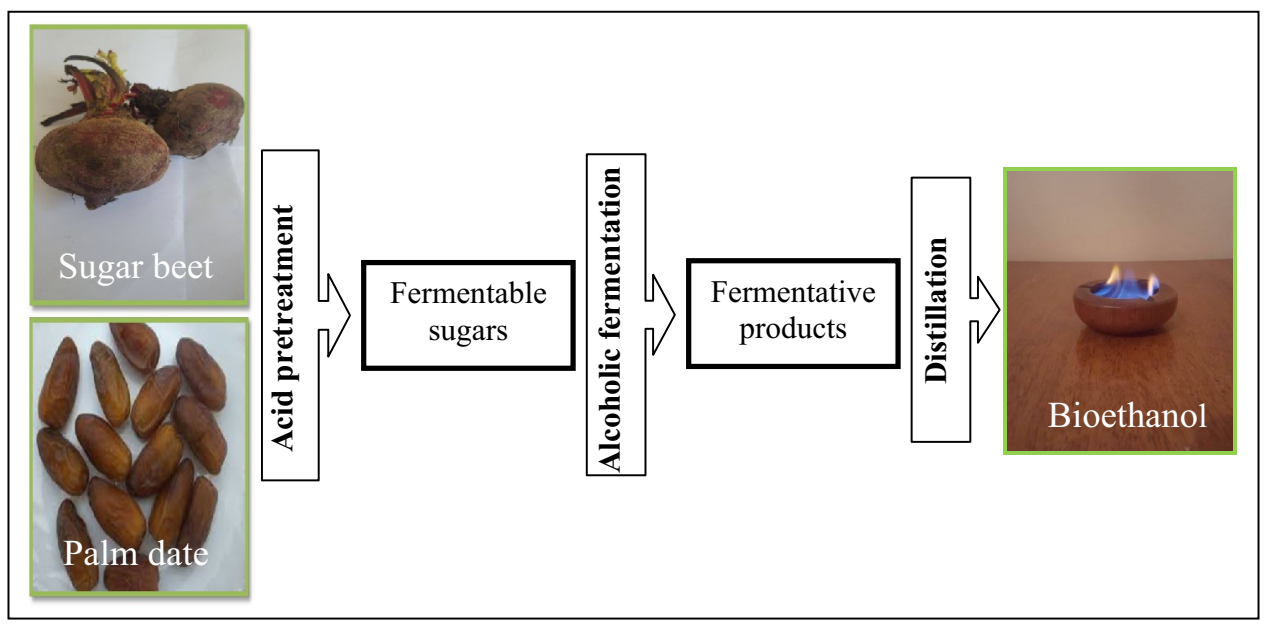

Keywords Alcoholic fermentation - Beet juice - Bioethanol · Date syrup - Energy recovery · Saccharomyces cerevisiae

\section{Introduction}

Fossil fuels (oil and natural gas) provide fast and efficient tools of transport as well as a good source of several industrial activities. However, their reserves are limited and security of supply is problematic for many countries importing this kind of fuels. On the other hand, their contribution to environmental pollution is a major problem [1]. Contemporary societies are always interested in finding substitutes for these fuels which must be renewable and environmentally sustainable. Thus, the waste-based energy rich in renewable organic matter (biomass) constitutes good raw materials for many industries and the recovery of biomass by biotechnological processes would be an economical and sustainable solution of energy supply. Special attention should be paid to agricultural byproducts (sugar beet, palm date, sugar cane, wheat, fruits, vegetables, etc.) since some fruits and vegetables of low quality cannot be integrated into human nutrition as they may have colors, tastes and aromas that are not appreciated [2-4]. Thus, a considerable part of this biomass is recognized as waste and not conflicting with food availability.

Agricultural residues are rich in organic matter but are unfortunately underutilized and often end up being polluters of the environment. These by-products can be valorized in order to produce bioethanol which can be used as alone or can be blended with gasoline as transportation fuels [5-7]. Bioethanol can be produced through fermentation of any raw materials as long as it contains sugar $[8$, 9]. Vegetables and fruits are very rich in carbohydrates. A successful conversion of these carbohydrates is considered as the most crucial step for bioethanol production. Thus, an efficient pretreatment should increase the content of fermentable sugars (glucose, fructose, galactose, etc.) and will results in a good yield of fermentative bioethanol $[6,10,11]$. Palm date is very rich in sucrose, fructose and glucose. Other simple sugars (oses) were identified in some date varieties; it is arabinose, xylose, galactose and mannose present at very low concentrations [12]. Palm date can therefore be good candidates for the production of bioenergy. In Algeria, one of the leading countries in the production and export of dates in the world, palm date cultivars are numerous and poorly exploited, with the exception of Deglat-Nour, Ghars, Deglat- Beida and Mech-Deglat, which are of major economic importance [12]. Thousands of tons of dates remain unused and can exceed $50 \%$ of year-round production, which could be valorized $[13,14]$. Sugar beet is also a typical feedstock for bioethanol production which is rich in hemicelluloses (24-32\%), and cellulose (22-30\%) (It has very low lignin content) [15]. The juice is fermented by yeast or bacteria. The chemical composition of sugar beet reveals a high content of fermentable sugars (arabinose, mannose and xylose) [16].The pulp, once drained, is used as animal feed or sold to the chemical, pharmaceutical or food industry.

The yeast Saccharomyces cerevisiae has long been an efficient agent for ethanol production at laboratory and industrial level with high efficiency [17-19]. It is considered as the world's premier industrial microorganisms being the best exploited microorganism in terms of both old and new biotechnologies [20]. The yeast tolerates a wide range of $\mathrm{pH}$ with an optimum under acidic 
conditions, which makes its fermentation less susceptible to infection than bacteria [21]. It also tolerates ethanol and inhibitory compounds better than other ethanol producing microorganisms. S. cerevisiae is considered as of major economic and social significance in human culture since it has long been used to produce alcoholic beverages (beer and wine) and ferment bread.

The objective of the present project was to propose a method of valorization of agricultural products in order to produce second-generation bioethanol. We opted for Algerian palm dates and sugar beets of low quality. Saccharomyces cerevisiae was the microorganism used to perform the alcoholic fermentation. The main goal was to develop an effective pretreatment of the selected raw material and alternative and efficient process for bioethanol production from a large variety of agro-industrial wastes.

\section{Materials and methods}

\subsection{Reagents}

All the chemicals used in the present work (acids, nutrient salts, etc.) were purchased from Merck.

\subsection{Selection and pretreatment of raw material (palm date and sugar beet)}

The sugar beet, Beta vulgaris from Algeria was used in the present work. It is a vegetable with a tuberous root, in which high amounts of sugar accumulate. The palm date used was Deglet-Nour which is the edible fruit of the date palm Phoenix dactylifera. It is highly coveted inside and outside the country because of its flavor and nutritional quality; it is a fleshy fruit containing an elongated core marketed mostly in the form of dry dates. The two products used in this work are of lower quality to be taken as residues of agriculture.

For the preparation of date syrup and beet juice, some pretreatments were carried out. They differ according to the nature of the raw material; the protocol was described in Fig. 1. In the case of sugar beet, two kinds of juice were prepared: beet juice with liming (BJL) and beet juice without liming. The operation of liming consists of a clarification of beet juice by calco-carbonic purification (addition of $\mathrm{CaCO}_{3}$ ) in order to precipitate impurities. To obtain $\mathrm{BJ}$, $40 \mathrm{ml}$ of $\mathrm{CaCO}_{3}(10 \mathrm{~g} / \mathrm{L})$ was added to the filtrate. Calcium carbonate fixes and precipitates impurities. The precipitate was then removed by a second filtration which led to a clear beet juice. Hydrolysis and neutralization were then carried out in the same way as for pretreatment without liming. The extracted date syrups and beet juices were stored in hermetic flasks at $4{ }^{\circ} \mathrm{C}$ until use.

The extraction was operated in a 500-ml flask equipped with a reflux condenser at a temperature of $65^{\circ} \mathrm{C}$ during $30 \mathrm{~min}$. This allowed a better extraction of sugars and a good consumption of the vegetable pulp.

\subsection{Characteristics of Saccharomyces cerevisiae}

Saccharomyces cerevisiae selected in the present work was that marketed in Algeria. It was inoculated in nutrient broth (supplemented with glucose and salts) at $30^{\circ} \mathrm{C}$ under shaking conditions to ensure the growth and activity conditions of the yeast. Cell density refered to the number of living cells per unit volume was measured at $600 \mathrm{~nm}$ (see Analytical techniques).

\subsection{Alcoholic fermentation experiments}

The fermentation assays were carried out in a $1 \mathrm{~L}$-batch bioreactor under magnetic stirring. The temperature was maintained at $30 \pm 2{ }^{\circ} \mathrm{C}$. A volume of $500 \mathrm{ml}$ of slightly heated juice or syrup $(\mathrm{pH}=4.5)$ was placed in the fermenter supplemented with nutrients necessary to promote rapid cell growth. Two grammes of yeast were then added to the reactor which must be quickly closed with a hermetic plug to ensure anaerobic conditions. Fermentation began once the release of $\mathrm{CO}_{2}$ was observed. The fermentation time was fixed at $72 \mathrm{~h}$ after which the bioethanol was recovered by distillation of the fermented mixture. The distillation temperature was of $78^{\circ} \mathrm{C}$. It was carried out in conventional equipment containing a heating bottle, refrigeration columns and a distillate recovery bulb.

Liquid samples for bioethanol determination were collected at the end of fermentation and filtered by a $0.45 \mu \mathrm{m}$ Millipore hydrophilic filter. The amount of $\mathrm{CO}_{2}$ released was measured by the liquid displacement method [13] (Fig. 2).

\subsection{Analytical techniques}

\subsubsection{Characterization of beet juice and date syrup}

Juice and syrup produced from raw materials were characterized by some physicochemical and biochemical parameters such as $\mathrm{pH}$, mass soluble solids (Brix), dry matter, total sugars and cell density.

- The Brix, measured by a refractometer, is a measure of total soluble solids (including sugars). It is based on the ability of a juice's sugar to deflect light. In the present work, the Brix of beet juice and date syrup 
Fig. 1 Pretreatments of sugar beet and palm date for the extraction of beet juice and date syrup

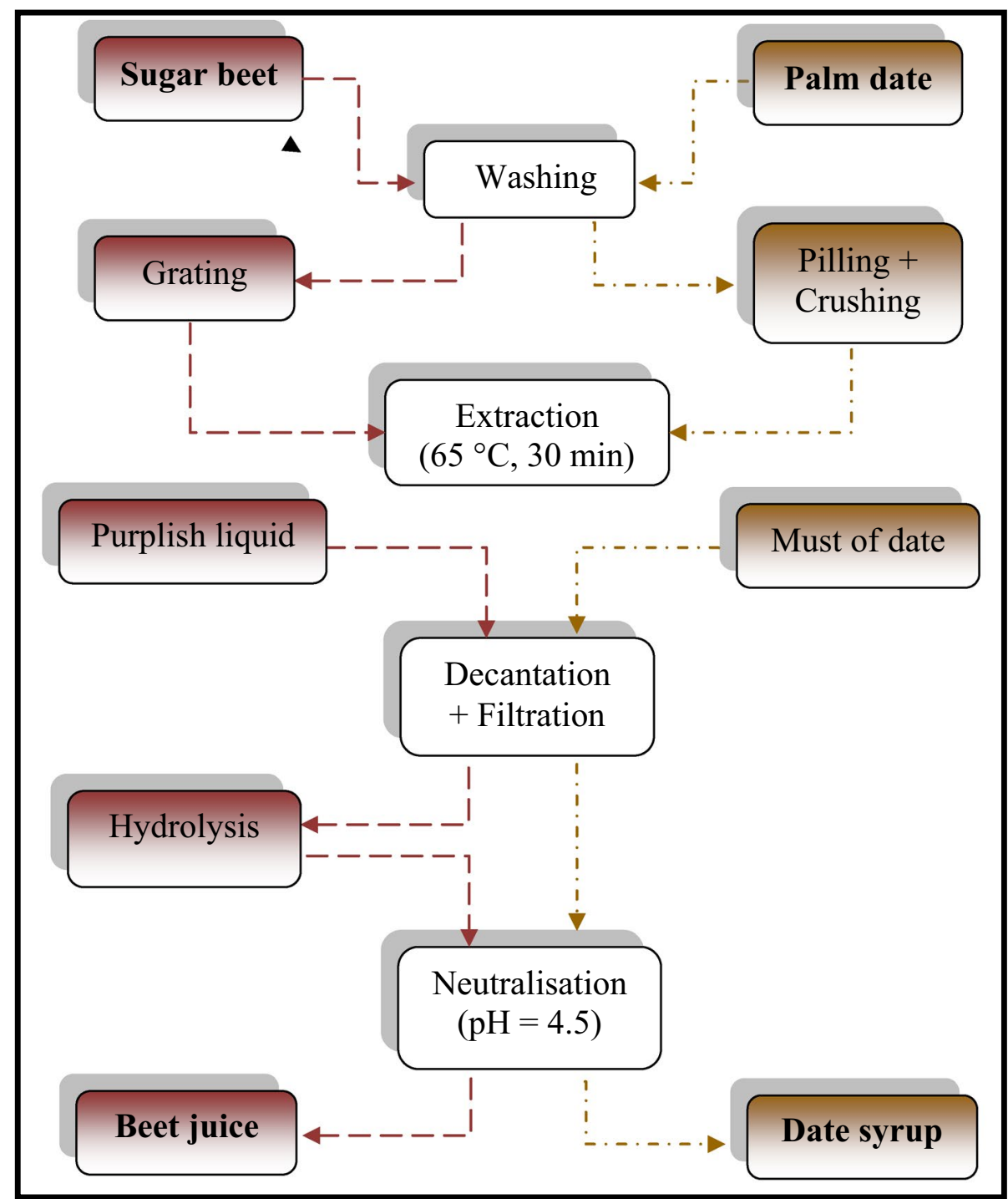

was made by measuring the refractive index at $20^{\circ} \mathrm{C}$ using an ATAGO RX-5000 type refractometer.

- The $\mathrm{pH}$ which is essential for the control of the substrate before and during fermentation is an indicator of the metabolic activity of the yeast during the transformation of sugars. Its measure was carried out by a $\mathrm{pH}$-meter Inolab $\mathrm{pH} 7110$.

- The dry matter (DM) was determined by drying in an oven at a temperature of $105^{\circ} \mathrm{C}$ until a constant weight a sample of $10 \mathrm{ml}$ of juice or syrup. It is expressed as:

$$
D M(\%)=\frac{M_{1}-M_{0}}{M_{2}-M_{0}} \times 100
$$

$M_{0}$ is the mass of the empty capsule $(g), M_{1}$ is the mass of the capsule and the residue after desiccation (g), $M_{2}$ is the mass of the capsule and the sample (g).
- Total sugars were determined by the phenol-sulfuric acid method based on the absorption of light at $448 \mathrm{~nm}$ [22]. A Secomam Prime-type spectrophotometer was used for this purpose.

\subsubsection{Cell density}

Cell density was measured at $600 \mathrm{~nm}$ (A600) using a Secomam Prime-type spectrophotometer. A600 values were converted into cell density $\left(10^{3} \mathrm{kcell} / \mathrm{mL}\right)$ by using a standard curve [23].

\subsubsection{Characterization of bioethanol}

The fermentative bioethanol was characterized by its physical appearance, smell and flammability. Its density, weight and concentration were also measured. Common techniques were used for this purpose. 
Fig. 2 Experimental setup of alcoholic fermentation

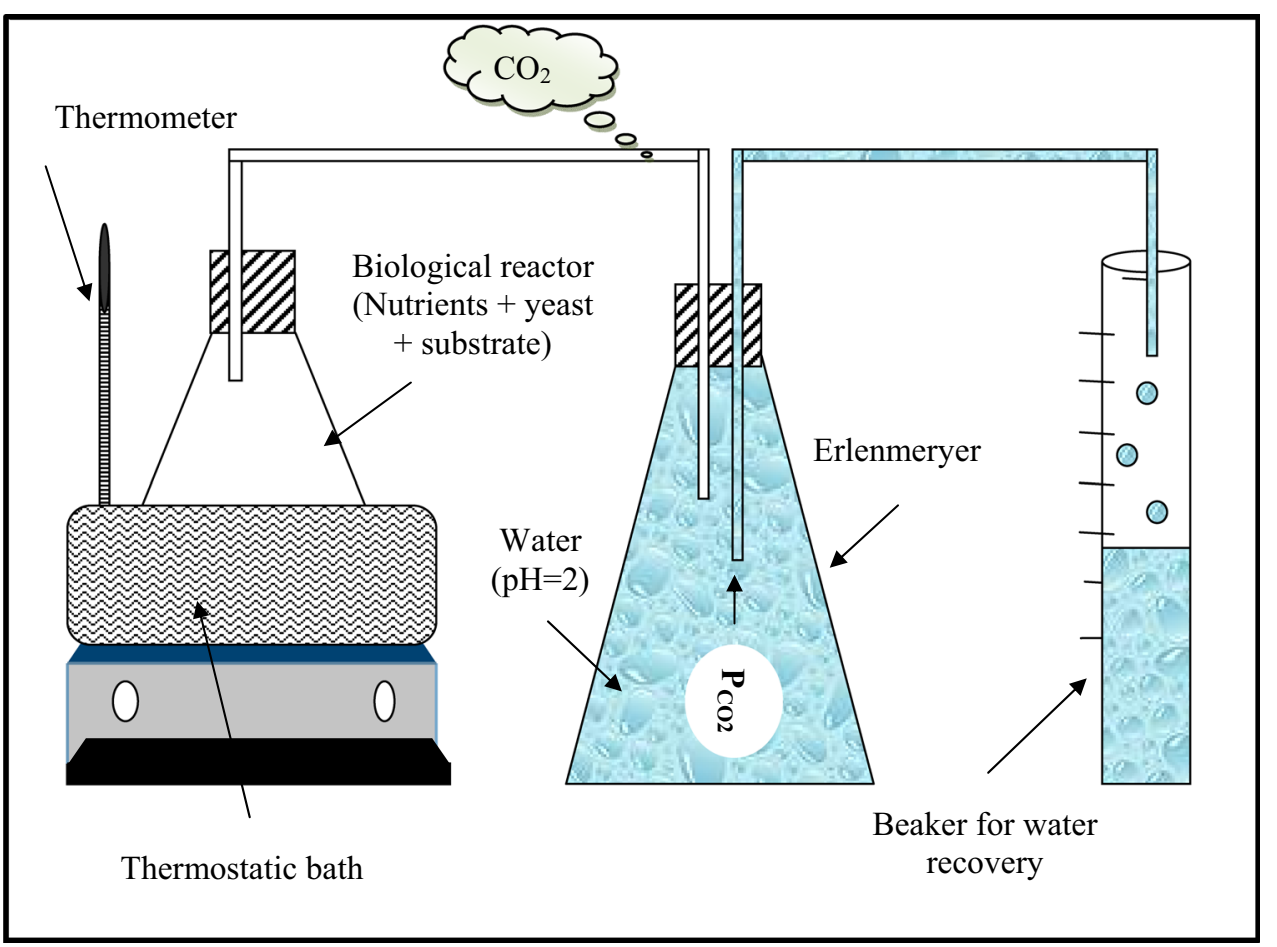

\subsubsection{Pressure of $\mathrm{CO}_{2}$}

The biological conversion was followed by measuring the $\mathrm{CO}_{2}$ release resulting from the fermentation following the degradation of sugars; $\mathrm{CO}_{2}$ production was measured by displacement of water (Fig. 2). The reactor was connected via a tube to an Erlenmeyer flask filled with water at $\mathrm{pH} 2$. The latter was connected by a second tube to an empty container. The $\mathrm{CO}_{2}$ produced in the reactor enters the flask exerting a pressure that will expel a quantity of water proportional to this pressure. This quantity of water recovered in the second container has a volume equivalent to the $\mathrm{CO}_{2}$ pressure.

The results were analyzed using a one-way analysis of variance (ANOVA). Comparison between the different treatments was statistically analyzed and the validity of investigation was expressed as probability value of $\mathrm{p}<0.05$.

\section{Results and discussion}

\subsection{Physicochemical proprieties of beet juice and date syrup}

Pretreatment is an important step in the conversion of biomass to bioethanol. In this study, an effective acid pretreatment was chosen to treat date and beet in order to convert the biomass into fermentable products. The different proprieties of beet juice and date syrup before conducting fermentation are given in Table 1. The five substrates appeared syrupy and viscous with a density varying between 0.99 and 1.05. Their color differs according to the nature of the raw material. Liming operation led to a beet juice with a lighter red color probably due to the elimination of impurities and some pigments. The $\mathrm{pH}$ of concentrated and diluted beet juice was around
Table 1 Physicochemical proprieties of beet juice and date syrup before fermentation

\begin{tabular}{|c|c|c|c|c|c|}
\hline \multirow[t]{2}{*}{ Parameter } & \multicolumn{3}{|c|}{ Beet juice } & \multicolumn{2}{|l|}{ Date syrup } \\
\hline & $4.8^{\circ}$ Brix & $3.1^{\circ} \mathrm{Brix}^{\mathrm{a}}$ & $2.2^{\circ}$ Brix & $22.1^{\circ}$ Brix & $12^{\circ}$ Brix \\
\hline $\mathrm{pH}\left(20^{\circ} \mathrm{C}\right)$ & 4.18 & 6.66 & 4.29 & 6.30 & 4.10 \\
\hline Density $\left(20^{\circ} \mathrm{C}\right)$ & 1.01 & 1.05 & 0.99 & 0.99 & 0.99 \\
\hline Total sugars (mg/L) & 47.14 & 30.07 & 17.21 & 220.1 & 110.8 \\
\hline Color & Dark red & Very light red & Light red & Dark brown & Light brown \\
\hline
\end{tabular}

Three independent experiments were performed for each assay. The values are expressed as mean \pm SD where $0.01 \leq \mathrm{SD} \leq 0.5$

${ }^{\mathrm{a}}$ Beet juice with liming 
4.2 which is an optimal value for the development of S. cerevisiae. The beet juice with liming had a $\mathrm{pH}$ value close to neutrality due to $\mathrm{CaCO}_{3}$ supplied during the liming operation. Concentrated beet juice was richer in total sugars than the two others with a value of $47.14 \mathrm{mg} / \mathrm{L}$. The liming operation was probably responsible for the lost of sugar amount from the juice $(30.07 \mathrm{mg} / \mathrm{L})$. Concentrated date syrup containing $220.1 \mathrm{mg} / \mathrm{L}$ of total sugar is considered as the most sugar-rich raw material used in the present study with a concentration of $220.1 \mathrm{mg} / \mathrm{L}$.

\subsection{Fermentation monitoring}

Saccharomyces cerevisiae represents the organism of choice for the production of ethanol at laboratory and industrial scale [23]. In this work, the time course of fermentation process was studied using the five substrates as a carbon source during $72 \mathrm{~h}$. The medium was, as described above, adjusted to initial $\mathrm{pH}$ of 4.5 and fermented at temperature of $30 \pm 2{ }^{\circ} \mathrm{C}$. The Yeasts also require appropriate supplies of nutrients, in order to efficiently carry out fermentation. Typical profiles of $\mathrm{CO}_{2}$ production were obtained for all the five substrates (Fig. 3). It was possible to define three standardized phases in the curves: (1) a lag phase (of about a few tens
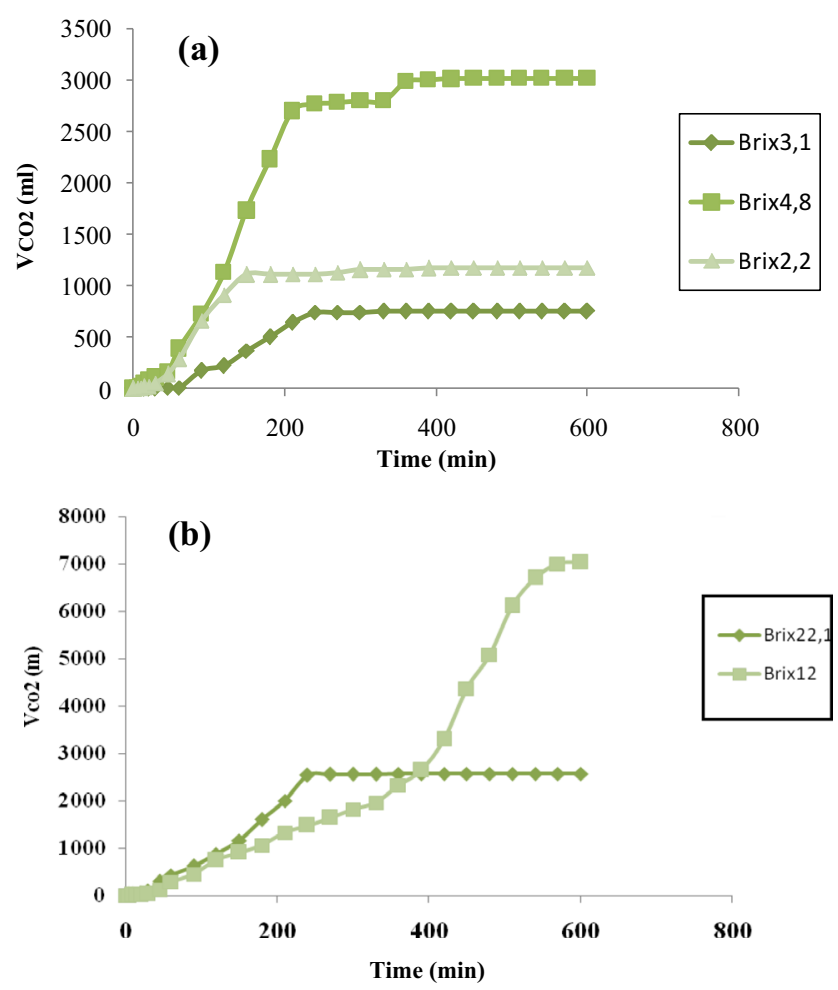

Fig. 3 Time course of fermentation for $\mathbf{a}$ beet juice and $\mathbf{b}$ date syrup for different Brix values

SN Applied Sciences

a SPRINGER NATURE journal of minutes) during which the yeasts adapt to the process conditions, (2) an exponential phase leading to assess the maximal biomass, and (3) a stationary phase. The highest biomass was reached at 3.0, 3.5 and $3.6 \mathrm{~h}$ in the presence of beet juice with $2.2,4.8$ and $3.2^{\circ} \mathrm{Brix}$, respectively (Fig. 3a). The yeast reached its highest biomass in the presence of date syrup $\left(12^{\circ} \mathrm{Brix}\right)$ after $10 \mathrm{~h}$ of fermentation (Fig. 3b). The concentrated syrup appeared to be less favorable than the diluted one for the development of yeast; this effect is probably attributed to the osmotic stress resulting from high sugar concentration of concentrated date syrup [23] or caused by some by-products (acids, aldehydes, esters, etc.) and/or non-metabolized components which can inhibit the yeast growth [24]. From these results, it is expected that the diluted date syrup would give a good quality bioethanol since alcohol production and yeast growth are inextricably linked [25].

\subsection{Physicochemical and biochemical characterization of fermentative products}

The fermentable sugars are metabolized by the yeasts that carry out bioconversion into bioethanol via fermentation. As well known, S. cerevisiae conduct fermentative metabolism to ethanol and carbon dioxide (as the primary fermentation metabolites) and also produce numerous secondary metabolites [25]. After alcohol fermentation, it was observed a decrease in the $\mathrm{pH}$ for all the substrates used in the resent work. This decrease was due to the formation of the carbon dioxide following the conversion of sugars into ethanol and making the medium more acid. This result was reported in several studies related to fermentation process with yeasts $[3,26]$. In a similar trend, total soluble solids (Brix) and total sugars decreased for the five substrates. Total soluble solids decreased by more than $60 \%$ in the case of beet juice $\left(4.8^{\circ}\right.$ Brix) and date syrup $\left(12.0^{\circ} \mathrm{Brix}\right)$. The yeast consumed more than $50 \%$ sugars of beet after $72 \mathrm{~h}$ of fermentation. Total sugars contained in concentrated syrup date were not consumed more than $18 \%$ while those contained in the diluted syrup date were converted to more than $63 \%$. The cell density of yeast led to estimate the quality of the fermentation process. The maximum cell density of $S$. cerevisiae in the present fermentation conditions was $8.4 .10^{3} \mathrm{kcell} / \mathrm{mL}$ with $12^{\circ}$ Brix of date syrup while the minimum cell density $\left(3.6 .10^{3} \mathrm{kcell} /\right.$ $\mathrm{mL}$ ) was obtained for concentrated date syrup. This result was confirmed by the formation of dense foam during the fermentation process. Finally, the results summarized in Table 2 show that the diluted syrup date (See the values marked in bold in Table 2) represents the best substrate 
Table 2 Physicochemical and biochemical characteristics of fermentative products

\begin{tabular}{|c|c|c|c|c|c|}
\hline \multirow{2}{*}{ Parameter } & \multicolumn{3}{|c|}{ Beet juice } & \multicolumn{2}{|l|}{ Date syrup } \\
\hline & $4.8^{\circ}$ Brix & $3.1^{\circ}$ Brix $^{a}$ & $2.2^{\circ}$ Brix & $22.1^{\circ}$ Brix & $12^{\circ}$ Brix \\
\hline $\mathrm{pH}\left(20^{\circ} \mathrm{C}\right)$ & 3.54 & 4.06 & 3.70 & 4.70 & 3.90 \\
\hline Density $\left(20^{\circ} \mathrm{C}\right)$ & 0.99 & 1.04 & 0.97 & 0.99 & 0.96 \\
\hline Total soluble solids ( ${ }^{\circ}$ Brix) & 1.8 & 2.4 & 1.5 & 19.5 & 4.5 \\
\hline Total sugars (mg/L) & 21.93 & 19.57 & 5.14 & 180.5 & 40.5 \\
\hline Cell density $\left(10^{3} \mathrm{kcell} / \mathrm{mL}\right)$ & 6.7 & 5.6 & 6.0 & 3.6 & 8.4 \\
\hline Dry matter (g/L) & 6.7 & 2.5 & 4.9 & 21.3 & 43.5 \\
\hline
\end{tabular}

Three independent experiments were performed for each assay. The values are expressed as mean \pm SD where $0.01 \leq \mathrm{SD} \leq 0.5$

${ }^{\mathrm{a}}$ Beet juice with liming
Table 3 Characterization of bioethanol produced by distillation

\begin{tabular}{|c|c|c|c|c|}
\hline Substrate & $\mathrm{d}(/)$ & Volume (ml) & Yield $^{b}$ (g/kg DM) & $\begin{array}{l}\text { Con- } \\
\text { centra- } \\
\text { tion } \\
\text { (g/L) }\end{array}$ \\
\hline $\begin{array}{l}\text { Beet juice (4.8 } \\
{ }^{\circ} \text { Brix) }\end{array}$ & 0.86 & 17 & 28.95 & 36.5 \\
\hline $\begin{array}{l}\text { Beet juice }{ }^{a}(3.1 \\
{ }^{\circ} \text { Brix) }\end{array}$ & 0.85 & 14.5 & 24,40 & 30.8 \\
\hline $\begin{array}{l}\text { Beet juice (2.2 } \\
{ }^{\circ} \text { Brix) }\end{array}$ & 0.88 & 8.0 & 14.22 & 17.6 \\
\hline $\begin{array}{l}\text { Date syrup (22.1 } \\
\text { 'Brix) }\end{array}$ & 0.86 & 36.4 & 63.24 & 78.2 \\
\hline $\begin{array}{l}\text { Date syrup (12 } \\
{ }^{\circ} \text { Brix) }\end{array}$ & 0.88 & 42.0 & 74.67 & 92.4 \\
\hline
\end{tabular}

a Beet juice: Beet juice with liming

${ }^{\mathrm{b}}$ The yield is defined as ratio of bioethanol to the mass of substrate

for the development of S. cerevisiae and the conversion of sugars.

\subsection{Bioethanol yield and concentration}

The physical and chemical pretreatments performed on beet and date materials were required to reduce recalcitrance biomass for hydrolyzing complex sugars (mainly sucrose) into simple intermediate products and increase the reactive surface area [2-21]. A comparison of the yield and concentration of ethanol of all fermentation processes is presented in Table 3. The values showed that alcohol obtained from the three substrates extracted from sugar beet had low concentration and yield ( $<29 \mathrm{~g} / \mathrm{kg} \mathrm{DM}$ ) suggesting that this raw material requires high pretreatments to hydrolyze sucrose into fermentable sugars. In parallel, for an initial soluble solids concentration of 12.0 'Brix, $92.4 \mathrm{~g} / \mathrm{L}$ of bioethanol was produced by $\mathrm{S}$. cerevisiae from date syrup. This concentration corresponded to an ethanol yield of $74.67 \mathrm{~g} / \mathrm{kg} \mathrm{DM}$. In the presence of concentrated date syrup ( $\left.22.2^{\circ} \mathrm{Brix}\right)$, a lower efficiency of ethanol production was observed $(78.2 \mathrm{~g} / \mathrm{L})$. These results corroborate with those of Chniti et al. [23] which attributed this effect to the osmotic stress resulting from high sugar concentration. Joshi et al. [24] on the other hand, assessed that the low efficiency of ethanol production may be due to an inhibition of the yeast growth, and consequently alcohol fermentation caused by some by-products or non-metabolized components. A flammability test was conducted with this bioethanol; a very intense and sustainable flame was obtained proving its good quality as a fuel. Although alcoholic fermentation with S. cerevisiae has long been improved, the present results showed that lower quality of Algerian dates, which cannot be integrated into human nutrition and are useless as animal feed due to low protein content [27] can be valorized for the production of ethanol with good quality (see the values marked in bold in Table 3) that could be used as fuel. On the other hand, sugar beet requires high pretreatments to hydrolyze some complex molecules (starch, cellulose, etc.) into fermentable sugars.

\section{Conclusion}

Regarding the efficiency of the fermentation, in respect to S. cerevisiae growth and ethanol yield, the results seemed to be promising. The ethanol yield was $74.67 \mathrm{~g} / \mathrm{kg}$ dry matter (DM) of original date material with a concentration of $92.4 \mathrm{~g} / \mathrm{L}$. Syrup extracted from Algerian dates of lower quality has the potential to be an industrially useful substrate for producing second-generation bioethanol. However, sugar beet requires high pretreatments to improve biomass digestibility by hydrolyzing complex sugars into fermentable sugars. Finally, to increase even more the productivity of this alcoholic fermentation process, factors inhibiting the bioethanol production should be identified and overcome. Thus, the extrapolation of the present process to the semi-pilot and pilot scale will be possible. Also, the search for other microorganisms 
capable of accelerating the process of alcoholic fermentation, increasing the conversion rate and producing a good ethanol is strongly encouraged.

Author contributions All authors contributed to the study conception and design. Material preparation, data collection and analysis were performed by Ibtissem FENNOUCHE and Nabila KHELLAF. The first draft of the manuscript was written by Nabila KHELLAF and all authors commented on previous versions of the manuscript. All authors read and approved the final manuscript.

\section{Compliance with ethical standards}

Conflict of interest The authors declare that there is no conflict of interest.

\section{References}

1. Pandiyan K, Singh A, Singh S, Saxena AK, Nain L (2019) Technological interventions for utilization of crop residues and weedy biomass for second generation bio-ethanol production. Renew Energy 132:723-741

2. Verardi A, Blasi A, Marino T, Molino A, Calabrò V (2018) Effect of steam-pretreatment combined with hydrogen peroxide on lignocellulosic agricultural wastes for bioethanol production: analysis of derived sugars and other by-products. J Energy Chem 27:535-543

3. Mansouri A, Rihani R, Laoufi AN, Özkan M (2016) Production of bioethanol from a mixture of agricultural feedstocks: biofuels characterization. Fuel 185:612-621

4. Abbès $F$, Bouaziz MA, Blecker $C$, Masmoudi $M$, Attia $H$, Besbes $S$ (2011) Date syrup: effect of hydrolytic enzymes (pectinase/cellulase) on physicochemical characteristics, sensory and functional properties LWT. Food Sci Technol 44:1827-1834

5. Derman E, Abdulla R, Marbawi H, Sabullah MK (2018) Oil palm empty fruit bunches as a promising feedstock for bioethanol production in Malaysia. Renew Energy 129:285-298

6. Khan MI, Lee MG, Shin JH, Kim JD (2017) Pretreatment optimization of the biomass of Microcystis aeruginosa for efficient bioethanol production. AMB Express 7:19

7. Ballerini $D$ (2011) Les biocarburants: répondre aux défis énergétiques et environnementaux des transports. Editions TECHNIP, France

8. Lin Y, Tanaka S (2006) Ethanol fermentation from biomass resources: current state and prospects. Appl Microbiol Biotechnol 69:627-642

9. Jha P, Singh S, Raghuram M, Nair G, Jobby R, Gupta A, Desai N (2019) Valorisation of orange peel: supplement in fermentation media for ethanol production and source of limonene. Environ Sustain 2:33-41

10. Chniti S, Djelal H, Hassouna M, Amrane A (2014) Residue of dates from the food industry as a new cheap feedstock for bioethanol production. J Biomed Bioeng 69:66-70

11. Solis JL, Davila R, Sandoval C, Guzmán D, Guzmán H, Alejo L, Kiros $Y$ (2019) Ethanol production from Schinus molle essential oil extraction residues. Waste Biomass Valoriz (in press)

12. Idder MA, Idder-Ighili H, Saggou H, Pintureau B (2009) Taux d'infestation et morphologie de la pyrale des dattes Ectomyelois ceratoniae (Zeller) sur différentes variétés du palmier dattier Phoenix dactylifera (L.). Cah d'Agriculture 18(1):63-71
13. Chibi S, El-Hadi D (2018) La bio-production de l'éthanol à partir de déchets de dattes: effet de l'incorporation des cendres du noyau de Deglet-Nour sur le rendement. Agrobiologia 8(1):685-694

14. Boulal A, Kihal M, Khelifi C, Benali B (2016) Bioethanol production from date palm fruit waste fermentation using solar energy. Afr J Biotechnol 15(30):1321-1627

15. Rezic T, Damir Oros D, Markovi I, Kracher D, Ludwig R, Šantek B (2013) Integrated hydrolyzation and fermentation of sugar beet pulp to bioethanol. J Microbiol Biotechnol 23(9):1244-1252

16. Dredge R, Radloff SE, van Dyk JS, Pletschke BI (2011) Lime pretreatment of sugar beet pulp and evaluation of synergy between ArfA, ManA and XynA from Clostridium cellulovorans on the pretreated substrate. 3 Biotech 1:151-159

17. Mohd Azhar SH, Abdulla R (2018) Bioethanol production from galactose by immobilized wild-type Saccharomyces cerevisiae. Biocatal Agric Biotechnol 14:457-465

18. Phwan CK, Ong HC, Chen W-H, ChuanLing T, Ng N, Show PL (2018) Overview: comparison of pretreatment technologies and fermentation processes of bioethanol from microalgae. Energy Convers Manag 173:81-94

19. Saravanan K, Duraisamy S, Ramasamy G, Kumarasamy A, Kumarasamy A, Balakrishnan S (2018) Evaluation of the saccharification and fermentation process of two different seaweeds for an ecofriendly bioethanol production. Biocatal Agric Biotechnol 14:444-449

20. Fakruddin M, Abdul Quayum M, Morshed Ahmed M, Choudhury N (2012) Analysis of key factors affecting ethanol production by Saccharomyces cerevisiae IFST-072011. Biotechnology 11(4):248-252

21. Lin Y, Zhang W, Li C, Sakakibara K, Tanaka S, Kong H (2012) Factors affecting ethanol fermentation using Saccharomyces cerevisiae BY4742". Biomass Bioenergy 47:395-401

22. Dubois M, Gilles KA, Hamilton JK, Rebeers PA, Smith F (1956) Calorimetric method for determination of sugars and related substances. Anal Chem 28:350-356

23. Chniti S, Jemni M, Bentaha I, Shariati MA, Kadmi Y, Djelal $H$, Amrane A, Hassouna M, Elmsellem H (2017) Kinetic of sugar consumption and ethanol production on very high gravity fermentation from syrup of dates (Phoenix dactylifera L.) by using Saccharomyces cerevisiae, Candida pelliculosa and Zygosaccharomyces rouxii. J Microbiol Biotech Food Sci 7(2):199-203

24. Joshi VK, Walia A, Rana NS (2012) Production of bioethanol from food industry waste: microbiology, biochemistry and technology. In: Baskar C, Baskar S, Dhillon R (eds) Biomass conversion. Springer, Berlin, pp 251-311

25. Walker GM, Stewart GG (2016) Saccharomyces cerevisiae in the production of fermented beverages. Beverages 2(30):1-12

26. Karadag D, Puhakka JA (2010) Direction of glucose fermentation towards hydrogen or ethanol production through on-line $\mathrm{pH}$ control. Int J Hydrogen Energy 35:10245-10251

27. Boulal A, Atabani AE, Mohammed MN, Khelafi M, Uguz G, Shobana S, Bokhari A, Kumar G (2019) Integrated valorization of Moringa oleifera and waste Phoenix dactylifera L. dates as potential feedstocks for biofuels production from Algerian Sahara: An experimental perspective. Biocatal Agric Biotechnol 20:101234

Publisher's Note Springer Nature remains neutral with regard to jurisdictional claims in published maps and institutional affiliations. 